\title{
ニューラルネットワークによる岩盤グラウチング のルジオン值推定システムの提案
}

\author{
貝沼憲男 ${ }^{1} \cdot$ 安田 登 $^{2} \cdot$ 松島 学 $^{3} \cdot$ 中川貴之 $^{4} \cdot$ 神藤健一 $^{5} \cdot$ 吉野尚人 $^{6}$ \\ 1フェロー 東京電力 (株) 電力技術研究所土木グループ(テ230-8510神奈川県横兵市鶴見区江ヶ崎町 4-1) \\ ${ }^{2}$ 正会員 工博 東京電力（株）電力技術研究所土木グループ(テ230-8510 神奈川県横浜市鶴見区江ヶ崎町 4-1) \\ ${ }^{3}$ 正会員 工博 東電設計 (株) 技術開発本部コンクリート・材料チーム(テ110-0015 東京都台東区東上野3-3-3) \\ ${ }^{4}$ 正会員 東電設計（株）技術開発本部コンクリート・材料チーム(テ110-0015 東京都台東区東上野3-3-3) \\ ${ }^{5}$ 工修 前田建設工業（株）技術研究所研究第3 グループ(テ179-8914 東京都練馬区九尤町 1-39-16) \\ ${ }^{6}$ 工修 前田建設工業 (株) 技術研究所研究第3 グループ(テ179-8914 東京都練馬区旭町 1-39-16)
}

ダム建設ではグラウチング工事か不可欠であり，施工管理にルジオン值が一般的に用いられている. グラウチン グ工事では，ルジオン值が目標の値になるまで繰り返される中央内挿法にしたがった方法が般的に採用されている. 本研究では，隣接孔から対象孔のルジオン值をニューラルネットワークを利用し，予測することを試みた. その結果 対象孔のルジオン值を精度良く予測でき, 経験豊富な現場技術者のもつ定性的な判断を定量的に表現することか可能 となった.

Key Words: neural network, grouting, Lugeon value, estimation, rock mass,

\section{1. はじめに}

ダム建設では, グラウチング工事 ${ }^{12}$ が不可欠であり, グ ラウチング工事の一つにカーテングラウチングがある. カーテングラウチングは, ダム提体下部および眝水池周 辺部でライン状に施工され，貯水池からの漏水量を低減 させることを目的として実施される. 通常, カーテング ラウチングの施工は「中央内挿法」と呼ばれる工法で実 施される. 中央内挿法とは，目標とする止水性確保さ れるまでボーリングれ間に新たなボーリング孔を削孔し グラウチングが行われるものである. グラウチングでは 岩盤の止水性を評価する方法としてルジオン值 ${ }^{2}(\mathrm{Lu})$ が 採用されている．新たなボーリング孔が必要か否かは, 周辺のルジオン值および単位注入セメント重量等から現 場技術者の経験等で判断されている. グラウチングの施 工完了基準は現場技術者により個人差があり, 豊富な経 験が無ければ判断できない.

このような状况を鑑み, 従来より多くの研究者がグラ ウチング工事の経済的・合理的な施工方法を模索してい

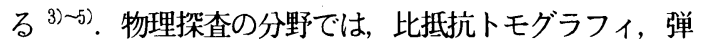
性波卜モグラフィ等を使用し, 岩盤の透水性亡相関のあ る物性值を把握する研究か報告されている ${ }^{344)}$. しかし, 代用された物性值之透水性亡の相関のばらつきが大きい ことから, 実用には至っていない. また, 対象とする孔
に隣接する孔の平均的なルジオン值と対象とする孔のル ジオン值を比較した報告もある ${ }^{5)}$ が, 定性的な評価にとど まっている.これらの研究は全て岩盤の透水性を正確に 把握することを目的としたものであり，末施工部分の透 水性を簡便に予測した研究はほとんと報告されていない， ボーリング削孔前に岩盤の透水性が把握できれば，無駄 な施工を省くことができ，経済的な施工が可能となる.

一方, 脳神経細胞を模擬した二ューラルネットワーク ${ }^{6)}$ が近年注目されている. ニューラルネットワークは, 非 線形性の高、現象を評価することに優れ, 本研究で取り 扱う岩盤のルジオン值を推定するには有効であると考え られる.

本研究では，Kダム建設地点の左岸リム部で施工され たグラウト工事の際に得られた岩盤内のルジオン值に影 響している因子を整理した，その結果をもとに，同一地 点でニューラルネットワークを用い，対象とする部分の 透水性を隣接孔から推定する手法を提案することで，グ ラウチング工事の経济的・合理的な施工実現を目指すこ とを目的としている.

2. カーテングラウチングとルジオン值の評価因子 カーテングラウチングはセメントと水を混合した「グ ラウト」と呼ばれる液体をボーリングれから岩盤内に圧 


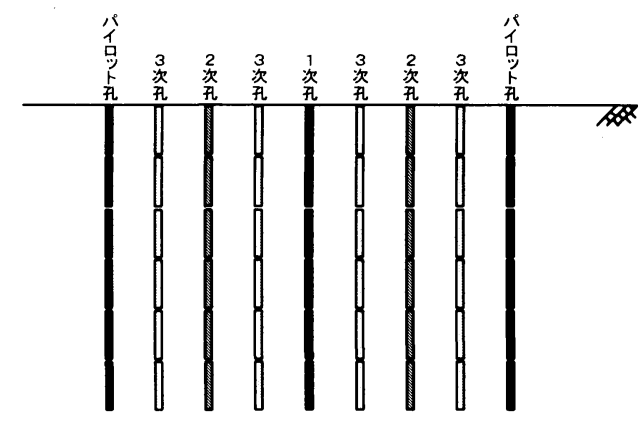

図-1，中央内挿法でのボーリング孔配置図

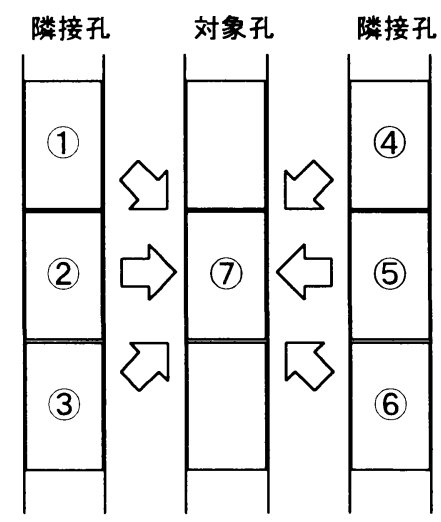

(1)左隣接ステージ上

(2)左隣接ステージ中

(3)左隣接ステージ下

(4)右隣接ステージ上 (5)右隣接ステージ中 6.右隣接ステージ下

(7)対象ステージ

図-2 対象ステージと隣接ステージの模式図

入することで実施される. カーテングラウチングは 1 つ の施工区間長を $5 \mathrm{~m}$ にしており，この $5 \mathrm{~m}$ 区分を 1 単位と して「ステージ」と呼び, グラウチング工事用のトンネ ルのインバートから深度方向順に 1 ステージ, 2 ステージ, 3 ステージ…としている. 本研究で用いる各種データもス テーシ沲のデータとなっている.

カーテングラウチングのボーリング削孔順序は一般に 中央内插法にしたがっている. 図-1に中央内插法でのボ ーリング孔の配置断面図を示す。中央内挿法の施工手順 を以下に示す.

(1)ある一定間隔 (本研究では $24 \mathrm{~m}$ ) で設けられた「パイロ ット孔」と呼ばれる地質調查兼用のボーリング孔を削 孔する. 削孔されたパイロット孔はルジオン試験, グ ラウチングが施される.

(2)パイロット孔の中間地点に「1次孔」之呼ばれるボーリ ング孔を削孔する. 1 次孔もパイロット孔亡同様な施工 を施す。

(3)パイロット孔と1次孔の中間地点に「2 次孔」と呼ばれ るボーリングれを削孔し, パイロット孔および 1 次孔

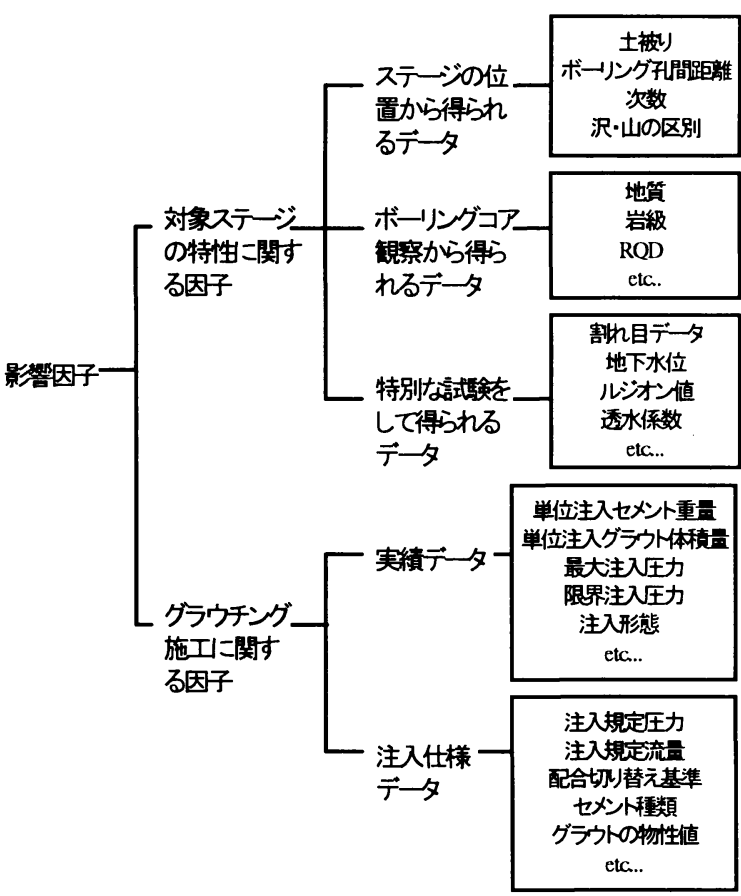

図-3 影響因子の分類

\section{と同様な施工をする.}

(4)以降「3 次孔，「4 次孔」…目標とする止水性か確 認されるまで施工を繰り返す。

グラウトがボーリング孔から同心円状に注入されると すると，グラウトの到達距離は施工深度にもよるが最高 でも約 $5 \sim 10 \mathrm{~m}$ 程度とされている7). 本研究では，対象と する孔のあるステージのルジオン值を予測する際にグラ ウトの到達可能距離を考虑し，左右の隣接する孔の同一 ステージと上下ステージの計 6 ステージのデータを採用 することにした. 予測するステージを含む孔を「対象孔!， 予測するステージを「対象ステージ」，対象孔に隣接す る孔を「隣接孔」，対象ステージに隣接する上，同一， 下ステージを「（左）（右）隣接ステージ（上）（中）

（下）」と以降表記する. 図-2 に対象ステージおよび隣 接ステージの模式図を示す.

一般に，中央内挿法に従ったカーテングラウチングで は, 深度か約 $100 \mathrm{~m}$ 以深の深部では岩盤の初期状態が目標 の改良值（約 2Lu）より透水性が低いことが多く，パイロ ット孔および1次孔で施厂か終了する場合が多い，一方， パイロット孔間距離が $24 \mathrm{~m}$ であることを考慮すると, 深 度が約 $100 \mathrm{~m}$ 以浅の浅部では 2 次孔まではライン状にグラ ウトが岩盤内に注入されていない場合が多く7，2次孔ま では前の次数孔でどのようなルジオン值か確認されても 施工する. つまり，ルジオン值を予測する際に最も重要 となるのは深度か約 $200 \mathrm{~m}$ 以浅の浅部での 3 次孔以降の予 
表-1 特別な試験を実施して得られるデー夕

\begin{tabular}{|l|l|}
\hline 因子 & 採取方法 \\
\hline 割れ目データ & $\begin{array}{l}\text { ボアホールスキャナ } \\
\text { ボアホールテレビ9) }\end{array}$ \\
\hline 地下水位 & 地下水位試(験 \\
\hline ル)
\end{tabular}

測である. 本研究では上記の理由により 3 次孔でのルジ オン值を予測することにした。

\section{3. ルジオン值に影響する因子の分析}

\section{（1）対象ステージのルジオン值に影響する因子}

本節では予めどのような因子が対象ステージのルジオ ン値に影響しているかを検討した。

図-3に対象ステージに影響すると考えられる因子（以 降「影響因子」と表記する）の分類を示す. 影響因子は, 対象ステージの特性に関する因子とグラウチング施工に 関する因子の 2 種類がある.

\section{a) 対象ステージの特性に関する因子}

対象ステージの特性に関する因子は，対象ステージの 位置から得られるデータ, ボーリングコア観察から得ら れるデー夕，特別な試験を実施して得られるデー夕の 3 種類である.

対象ステージの位置から得られるデー夕は, 対象ステ 一ジの上方にある被りの高さ（以降「土被り」と表記す る）,ボーリング孔間距離，次数，沢部であるか山部で あるかの区別等である.これらのデー夕は施工時に自動 的に得られ, 対象ステージのルジオン值の評価因子とし て十分な数量を得ることができる. ボーリングコア観察 から得られるデー夕は, 地質, 岩級, RQD等である. 通常, ボーリングコアは調査孔でのみ採取されるため, これら の值は 1 次孔以降の次数孔では採取か涃難之なる. 特別 な試験を実施して得られるデー夕は，割れ目デー夕（走 向, 傾斜, 割れ目数, 割れ目幅等), 地下水位, ルジオ ン值等である. それぞれのデー夕の採取方法を表-1 に示 す. 表-1 の各データのうち，グラウチング実施時に常時 得られるデータはルジオン值のみである.

b) グラウチング施工に関する因子

グラウチング施工に関する因子は，実績データと注入 仕様データの 2 種類がある.

実績データはグラウチングが実施されたことで岩盤内 の透水性をどの程度改良したかを把握するものであり， 単位注入セメント重量, 単位注入グラウト体積量, 注入 最大圧力，注入限界圧力，注入形態（浸透注入，割裂注 入等）等があげられる.このうち岩盤内の透水性をどの 程度改良したかを最も端的に表しているのは単位注入セ メント重量である，単位注入グラウト体積量が同一でも

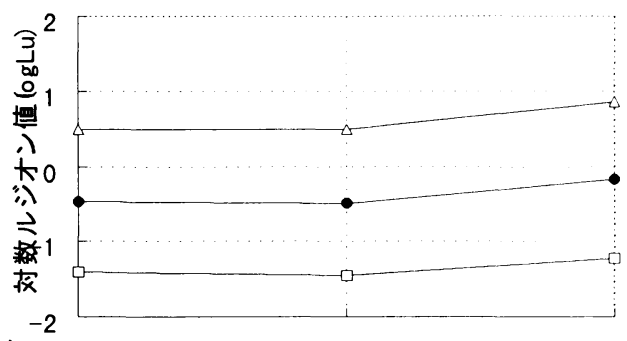

安山岩系

入岩系

角礫岩系

図-4 地質区分と対数ルジオン值の関係

表-2 地質区分のデー夕数

\begin{tabular}{|c|c|c|c|c|}
\hline & 安山岩系 & 貫入岩系 & 角碟岩系 & 合計 \\
\hline デー夕数 & 456 & 1251 & 527 & 2234 \\
\hline
\end{tabular}

グラウトの配合によってセメント重量に変化があり，対 象ステージのルジオン值との関係を考えるには問題があ る. 注入限界圧力, 注入形態 (浸透注入, 割裂注入等) はグラウチングの効果として対象ステージのルジオン值 に影響しているが, 評価の方法が難しく, 評価する個人 によって大きく左右されるため対象ステージのルジオン 值亡の関係を考えるには問題がある.

注入仕様データはグラウチングを実施する際に予め設 けるものであり, 注入規定圧力, 注入規定流量, 配合切 り替え基準，使用セメントの種類，グラウト材料の物性 值（粘性係数，フロ一值，比重等）等がある. 注入仕様 デー夕は, 対象ステージのルジオン值に影響するが, 同 一の地点では同様な注入仕様でのグラウチングが行われ る場合が多く, 対象ステージのルジオン值の評価因子と はならない。

\section{（2）対象ステージのルジオン值と影響因子の相関}

各影響因子と対象ステージのルジオン值との相関につ いて具体的なカーテングラウチングのデー夕を用いて検 討する. 影響因子を検討する際には, K夕゙ム建設地点の 左岸リム部で施工されたカーテングラウチングの全デー 夕を使用した. したがって，地盤の生成過程や，変状に よる基本的な性質は同じ母集団に属すると判断し，本研 究で設定した因子でグラウチングの施工を説明できると した．対象地点の状况については，各影響因子の検討の 項目で詳述する. なお，本節ではルジオン值の対数をと

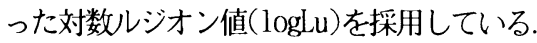




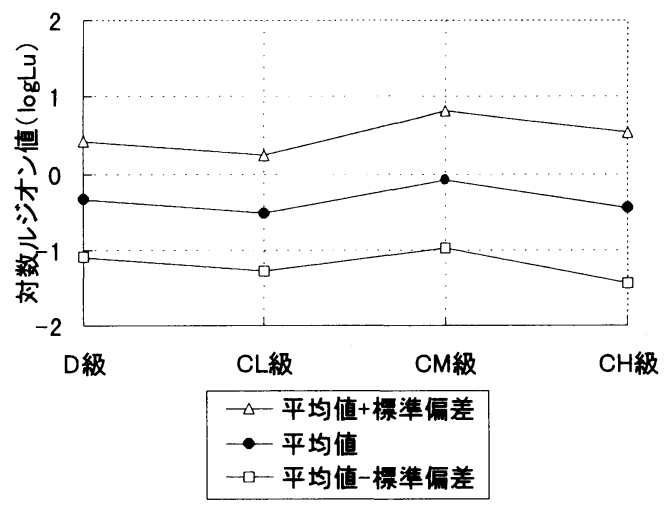

図-5 岩級区分と対数レレジオン值の関係

表-3 岩級区分のデー夕数

\begin{tabular}{|c|c|c|c|c|c|}
\hline & D 級 & CL 級 & CM 級 & CH 級 & 合計 \\
\hline デ-多数 & 27 & 54 & 242 & 1911 & 2234 \\
\hline
\end{tabular}

a) 地質と対数ルジオン值の関係

地質と対数ルジオン值の関係を図-4 に示す．表-2には 各地質のデー夕数を示す.

対象地点ではパイロット孔のみでボーリングコアが採 取されているため, 図4 はパイロット孔での地質之対数 ルジオン值の関係を示している. 確認された地質は, 安 山岩系, 貫入岩系, 角碟岩系の 3 種類であった.

図中に各地質での対数ルジオン值の平均値および平均 值土標準偏差を示す．同図より，角喽岩系が他の 2 つの 地質よりも対数ルジオン值が大きくなっているが, 明確 には判断できない，岩盤を構成する地質は，巨視的には 透水性を把握する際に有用なデータであり，微視的な透 水性にも若干影響していることが従来より指摘されてい る ${ }^{11)}$. しかし, 本研究で取り扱う対数ルジオン值亡の相 関を考えるには他の影響因子のばらつきの中に本因子の 傾向が埋もれてしまい，地質のみで評価することが困難 である. つまり，単相関での検討では，本因子がルジオ ン值に影響しているかどうかは判断できないと考えられ る.

\section{b) 岩級と対数ルジオン值の関係}

岩級之対数ルジオン值の関係について図-5 に示す. 表 -3 に各岩級のデー夕数を示す. 対象地点ではパイロット 孔のみでボーリングコアか棌取されているため, 図-5で はパイロット孔での岩級と対数ルジオン值の関係を示し ている. 対象地点の岩級は CH 級，CM 級， CL 級，D級の 4 種類であった. 表-3より他の岩級と比較してCH 級のデー 夕数か極めて多いことから，対象地点は堅硬な岩が多く 分布していると考えられる. 図-5 中には各岩級での対数 ルジオン值の平均値および平均值土標準偏差を示してい る. 一般に岩級は，対数ルジオン值とは密接な関係があ

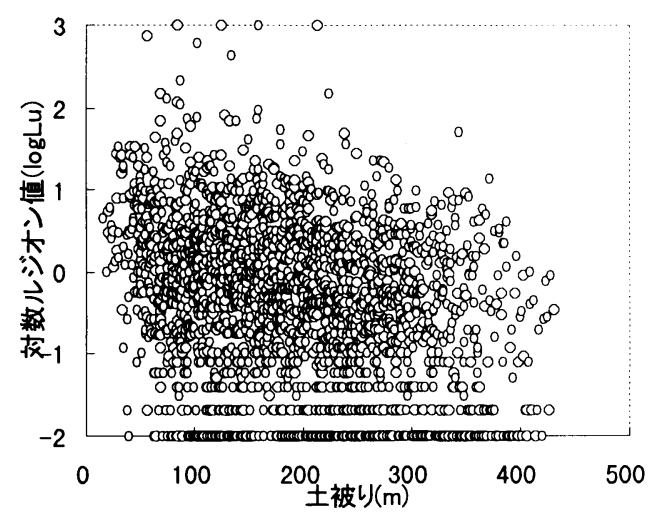

図-6 土被りと対数ルジオン值の関係

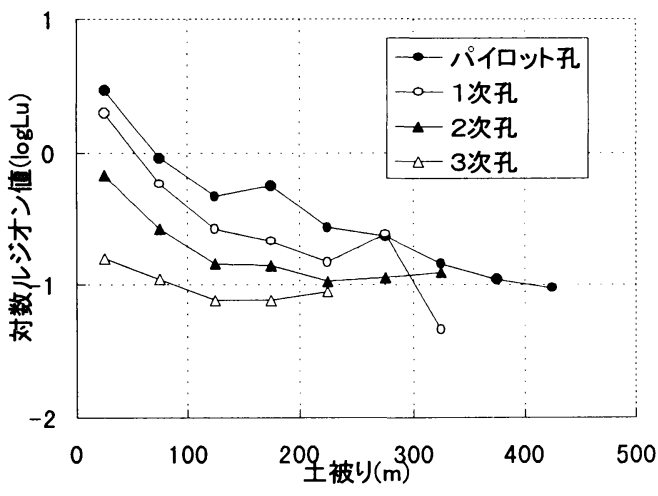

図-7 土被りと対数レジオン値の関係（区間平均）

表-4 次数別の土被り各区間のデー夕数

\begin{tabular}{|c|c|c|c|c|c|c|}
\hline $\begin{array}{c}\tilde{广}^{*}-\text { 夗間 } \\
\text { (深度) }\end{array}$ & $\begin{array}{c}\text { 中央 } \\
\text { 值 }\end{array}$ & $\begin{array}{c}\Lambda^{\circ} \text { 何 } \\
\text { 忏 }\end{array}$ & 1次孔 & 2次孔 & 3 次孔 & 合計 \\
\hline$(\mathrm{m})$ & $(\mathrm{m})$ & \multicolumn{5}{|c|}{ テー夕数 } \\
\hline $0 \sim 50$ & 25 & 65 & 61 & 113 & 105 & 344 \\
\hline $50 \sim 100$ & 75 & 342 & 356 & 670 & 350 & 1718 \\
\hline $100 \sim 150$ & 125 & 410 & 420 & 788 & 347 & 1965 \\
\hline $150 \sim 200$ & 175 & 410 & 410 & 719 & 216 & 1755 \\
\hline $200 \sim 250$ & 225 & 405 & 335 & 511 & 74 & 1325 \\
\hline $250 \sim 300$ & 275 & 311 & 99 & 182 & - & 592 \\
\hline $300 \sim 350$ & 325 & 201 & 30 & 44 & - & 275 \\
\hline $350 \sim 400$ & 375 & 88 & - & - & - & 88 \\
\hline $400 \sim 450$ & 425 & 22 & - & - & - & 22 \\
\hline 合計 & & 2254 & 1711 & 3027 & 1092 & 8084 \\
\hline
\end{tabular}

るとされている ${ }^{12)}$. しかし, D 級の岩盤でも岩が粘土質に 変化していたりすると逆に低透水性を示したりすること があり，一概に対数ルジオン值と相関があるとは言えな い. 図-5 は，そのような現象も含んでおり，岩級之対数 ルジオン值には明確な相関が見られない，さらに，対象 地点の岩級はほとんどがCH 級であり，岩級のみで対数ル 湆オン值との相関を評価するのは困難があると考えられ る. これは，地質の検討と同様な結果であり，単相関で 
の検討では，本因子がルジオン值に影響しているかどう かは判断できないと考えられる.

\section{c）土被りと対数ルジオン值の関係}

パイロット孔での土被りと対数ルジオン值の関係を図 -6 に示す. 1 次孔 3 次孔の図も図-6 之同様なものであ り，一見しただけではその相関について考えるのは難し いものであった：図一7には，土被りを50m 区切りで区分 し, それぞれの領域での対数ルジオン值の区間平均の值 を次数孔別に示している. 表-4 には次数別の土被り各区 間のデー夕数を示している. 図一7には示していないが標 準偏差（各領域でのばらつき程度）は全ての区間で約 1(logLu)であり, 次数孔による差は無かった. 図一より, 土被りが小さい領域では次数増に伴い対数ルジオン值が 小さくなる傾向にある. しかし, 土被りの大きい領域で は次数か増加しても対数レジオン值に変化が無い.これ は，土被りの小さい領域でグラウチングによる改良が大 きくなされたことを示している. 各次数孔別にみると, 土被りが大きくなるほど対数ルジオン值が小さくなる傾 向にある.これは土被りが大きくなることで割れ目幅が 小さくなったり, 割れ目数が少なくなったりするためと 考えられる.このように, 定性的ではあるが土被りと対 数ルジオン值は相関があると考えられる.

\section{d) 上ステージの単位注入セメント重量と対数ルジオン值 の関係}

グラウチングが浅部から深部に向かって施工される場合 (フォアステージ工法 ${ }^{13)}$ )，上ステージのグラウトか下 ステージに回り込み, ルジオン值が過小評価されること がある. 本研究では，この現象を「目薬効果」と以降呼 称する. 図-8にパイロット孔での上ステージの単位注入 セメント重量と対数ルジオン值の関係を示す. 1 次孔 3 次孔の図も図-8 亡同様なものであり，一見しただけでは その相関について考えるのは難しいものであった．同図 は，単位注入セメント重量の対数をとった対数単位注入 セメント重量 $(\log (\mathrm{kg} / \mathrm{m}))$ を採用している. 図-9に単位注 入セメント重量を $1(\log (\mathrm{kg} / \mathrm{m}))$ で 1 区切りした場合の各 領域での対数ルジオン值の区間平均の值を次数別に示し ている. 表-5には, 次数別の上ステーシ対数単位注入セメン 卜重量の各区間のデー夕数を示している. 各区間での標準偏 差はほぼ等しく, 約 $1(\log \mathrm{Lu})$ であった. 図-9 からは, 目 薬効果の傾向を読みとることは困難である. しかし，100 $\sim 1000(\mathrm{~kg} / \mathrm{m})$ および $1000(\mathrm{~kg} / \mathrm{m})$ 以上の領域では, 上ステ ージ単位注入セメント重量が増加しても対数ルジオン值 に変化が無いような傾向がある.これは，上ステージの 単位注入セメント重量が極めて大きい場合, 対数レジオ ン值が過小評価されていることを示していると考えられ る. あるステージが目薬効果の影響を受けるかどうかは, 割れ目の走向, 傾斜, 上ステージの単位注人セメント重 量等が複雑に影響していると考えられるが, 簡略化して

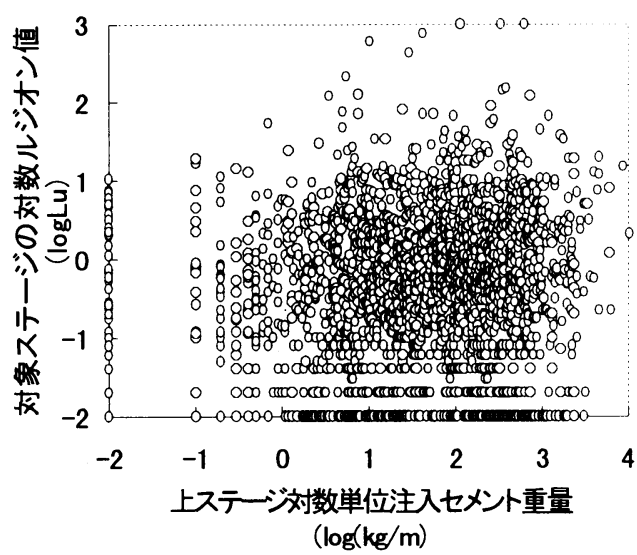

図-8 上ステージ対数単位注入セメント重量と対象ステージ対 数レジオン值の関係

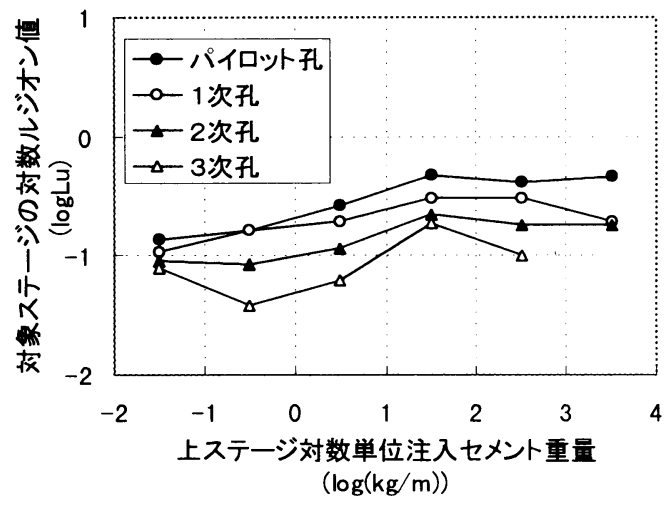

図-9 上ステージ対数単位注入セメント重量と対象ステージ対 数ルジオン值の関係 (区間平均)

表-5 次数別上ステージ対数単位注入セメント重量各区間のデ 一夕数

\begin{tabular}{|c|c|c|c|c|c|c|}
\hline 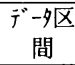 & 中央值 & $\begin{array}{c}\Lambda^{\circ} \text { 㐰 } 卜 ~ \\
\text { 孔 }\end{array}$ & 1 次孔 & 2次孔 & 3次孔 & 合計 \\
\hline \multicolumn{2}{|c|}{$\log (\mathrm{kg} / \mathrm{m})$} & \multicolumn{4}{|c|}{ デ-夕数 } & \\
\hline$-2 \sim-1$ & -15 & 75 & 29 & 73 & 16 & 193 \\
\hline$-1 \sim 0$ & -0.5 & 157 & 110 & 301 & 227 & 795 \\
\hline $0 \sim 1$ & 0.5 & 423 & 373 & 901 & 343 & 2040 \\
\hline $1 \sim 2$ & 1.5 & 705 & 497 & 972 & 2319 & 2493 \\
\hline $2 \sim 3$ & 25 & 779 & 602 & 692 & 120 & 2193 \\
\hline $3 \sim 4$ & 3.5 & 130 & 63 & 32 & - & 225 \\
\hline 合計 & & 2269 & 1674 & 2971 & 1025 & 7939 \\
\hline
\end{tabular}

上ステージの単位注入セメント重量のみに限定して考え ると，図-9より $100(\mathrm{~kg} / \mathrm{m})$ 以上は目薬効果の影響を受け ている可能性があると考えられる. 本研究では，上ステ ージの単位セメント重量が $500(\mathrm{~kg} / \mathrm{m})$ 以上であれば, 対象 ステージが明らかに目薬効果を受けたステージであると 仮定し，ニューラルネットワークの入力項目として使用 した. 


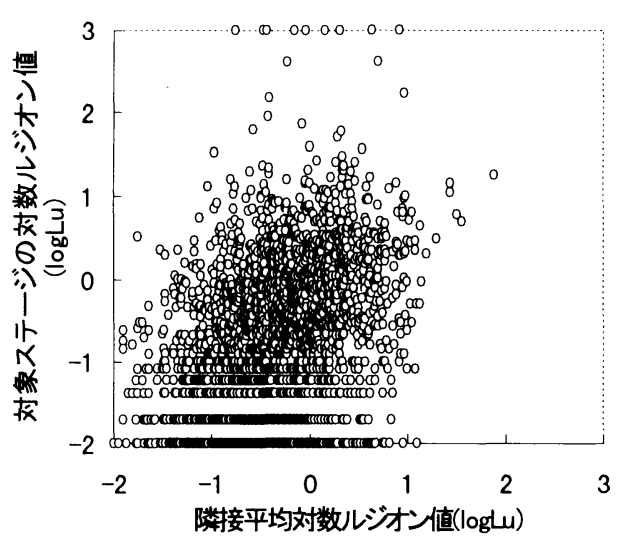

図-10 隣接平均対数レジオン值と対象ステージの対数Uレジ オン值の関係

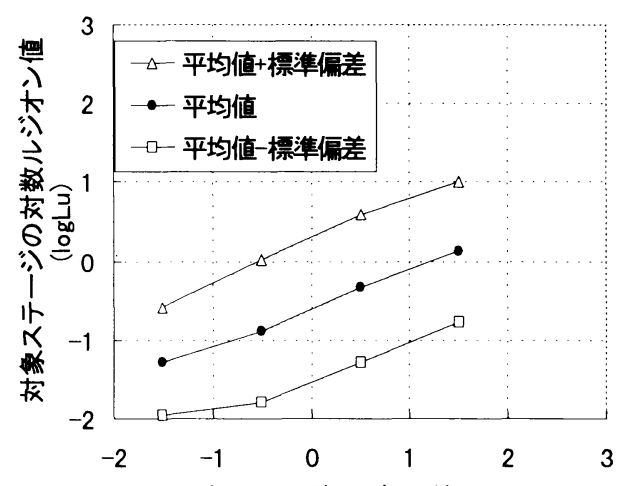

隣接平均対数ルジオン值(logL)

図-11 隣接平均対数レジオン值と対象ステージの対数ルジ オン値の関係 (区間平均と標準偏差)

表6 隣接平均対数ルレジオン值の各区間のデー夕数

\begin{tabular}{|c|c|c|}
\hline $\bar{T}^{*}-$ 夕区間 & 中央值 & デー夕数 \\
\hline$(\log L u)$ & $(\log L u)$ & \\
\hline$-2 \sim-1$ & -1.5 & 353 \\
\hline$-1 \sim 0$ & -0.5 & 1518 \\
\hline $0 \sim 1$ & 0.5 & 717 \\
\hline $1 \sim 2$ & 1.5 & 22 \\
\hline 合計 & & 2610 \\
\hline
\end{tabular}

e) 隣接孔のルジオン值と対象ステージの対数ルジオン值 の関係

本節では隣接孔の対数ルジオン值と対象孔の対数ルジ オン值の関係を対象孔が 2 次孔である場合を例にして示 す.

図-10 に左右隣接ステージ上中下 (パイロット孔および 1 次孔) の対数ルジオン值の平均值（「隣接平均対数ルシ オン值」と以降呼称する）亡対象ステージ（2次孔）の対

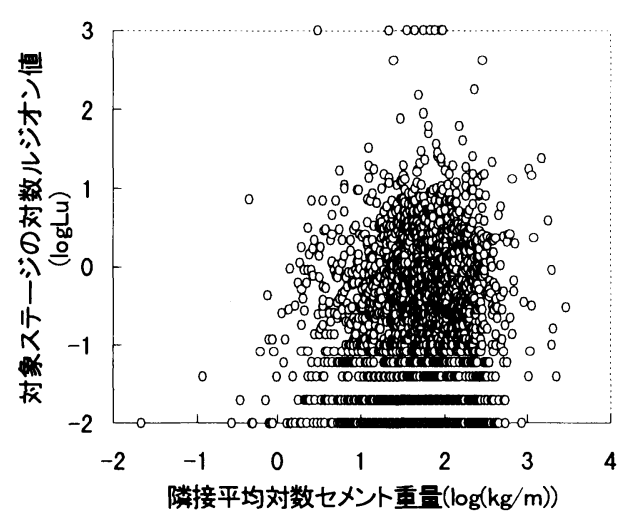

図-12隣接平均対数セメント重量と対象ステージの対数ル ジオン値の関係

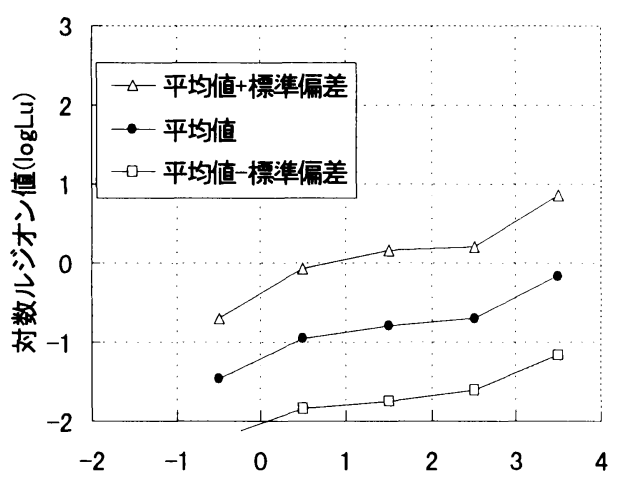

隣接平均対数セメント重量 $(\log (\mathrm{kg} / \mathrm{m}))$

図-13隣接平均対数セメント重量と対象ステージの対数ル ジオン值の関係（区間平均と標準偏差）

表-7 隣接平均対数セメント重量の各区間のデー夕数

\begin{tabular}{|c|c|c|}
\hline デ-夕区間 & 中央值 & デー夕数 \\
\hline$(\log (\mathrm{kg} / \mathrm{m}))$ & $(\log (\mathrm{kg} / \mathrm{m}))$ & \\
\hline$-1 \sim 0$ & -0.5 & 19 \\
\hline $0 \sim 1$ & 0.5 & 255 \\
\hline $1 \sim 2$ & 1.5 & 1558 \\
\hline $2 \sim 3$ & 2.5 & 765 \\
\hline $3 \sim 4$ & 3.5 & 13 \\
\hline 合計 & & 2610 \\
\hline
\end{tabular}

数ルジオン值の関係を示す. 図-11 に隣接平均対数ルジオ ン值を $1(\log L u) て ゙ 1$ 区切りした領域での対象ステージの 対数ルジオン值の区間平均の值を示す. 表 6 に，隣接平 均対数ルジオン值の各区間のデー夕数を示す. 隣接平均 対数ルジオン值と対象ステージのルジオン值は岩盤内の 割れ目が連結している場合に密接な関係がある. 図一11よ り隣接孔のルジオン值が大きくなると対象孔のルジオン 值は大きくなることがわかる. 以上より，対象ステージ 
のルジオン值は大きくばらつきはするものの，隣接孔の ルジオン值か密接に関係していることがわかる.

\section{f) 単位注入セメント重量と対象ステージの対数ルジオン 值の関係}

本節では隣接孔の対数単位注入セメント重量と対象孔 の対数ルジオン值の関係を対象孔が 2 次孔である場合を 例に示す. 図-12に左右隣接ステージ上中下 (パイロット 孔および 1 次孔) の対数単位注入セメント重量の平均値 （「隣接平均対数セメント重量」と以降表記する）之対 象ステージ (2 次孔) の対数ルジオン值の関係を示す. 図 -13 に隣接平均対数セメント重量を $1(\log (\mathrm{kg} / \mathrm{m}))$ で 1 区 切りした領域での対象ステージの対数レジオン值の区間 平均の值を示す. 表-7に隣接平均対数セメント重量の各区間 のテー夕数を示す. 隣接平均対数セメント重量と対象ステ ージのルジオン值は, e)での結果亡同様に岩盤内の割れ 目が連結している場合には密接な関係がある. 図-13より, 隣接孔の単位注入セメント重量が大きくなると対象ステ 一ジのルジオン值は大きくなる. 以上より, 対象ステー ジのルジオン值は大きくばらつくものの隣接孔の単位注 入セメント重量か滵接に関係している.

以上 a) f)の検討より, 対象ステージのルジオン值に 影響しているデータの概要が明らかとなった. しかし, その相関は極めて曖昧なものであり定性的なものでしか ない，さらに，各々のデー夕の相関は線形ではなく，非 線形性に卓越したものであると考えられる.これらのテ 一夕の相関を定量的に把握するには非線形性の問題に有 効な解析モデルが必要であると考えられる.

\section{4. ニューラルネットワークシステムの入出力項目}

ニューラルネットワークは脳神経細胞におけるニュー ロンとシナプスを数学的にセルとネットワークでモデル 化し, よく吟味された入出力の組み合わせを学習させる ことで, 複雑な非線形性の強いモデルに対しても適応能 力が高くなる ${ }^{14)}$. 入出力項目の決定には, 事前にデー夕 を吟味し，採取されたデータのスケーリングを行う必要 がある. 本研究では，3.で検討した影響因子の中から比 較的簡単に入手でき, 対象ステージのルジオン值と相関 があると考えられる因子を入出力項目として採用するこ とにした. ニューラルネットワークのシステムの入出力 に使用したデータは，K夕゙ム建設地点左岸リム部のカー テングラウチング施工の一部領域のうち, 出力值が 3 次 孔のものである.K夕゙ム建設地点左岸りム部の初期ルジ オン值の傾向は，領域によって異なっていた．明らかに 傾向の異なる領域を 1 つのシステムとして評価すること はシステムの精度を低下させると考え，深度に対して同 様な傾向を示す領域を左岸りム部から選択した。

ニューラルネットワークの入出力項目の関係を図-14

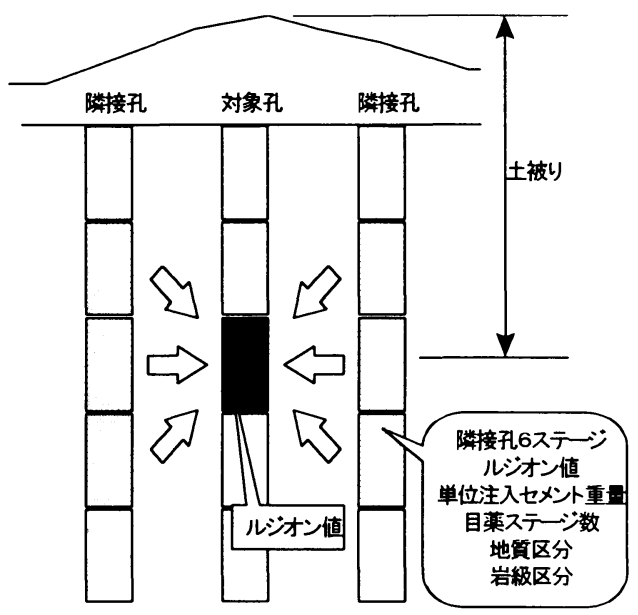

図-14 ニューラルネットワークの人出力項目の関係

に示す. 以下に各入出力項目の詳細を示す.

\section{(1) 隣接孔のルジオン値}

隣接孔のルジオン值は定量的な数值データであり, 対 象ステージのルジオン值と密接に関係していると考えら れる. 入力テータは, 左右粼接ステージ上中下の合計 6 データであり, 入力ニューロン数は 6 とした. ルジオン 値の分布は次数孔によって異なるが，全般的に極めて小 さい值(0〜1Lu)に集中しており, 突出して大きい値のデ 一夕をそのまま学習させると全体の傾向を捉えにくくし， 感度に問題のあるデー夕となる. 実施工では, 隣接孔で 極めて大きいルジオン值か確認された場合には安全を考 慮し必ず次のボーリング孔を削孔する.つまり，極めて 大きいルジオン值の推定は問題ではなく, 最む施工完了 基準か曖昧となる領域は 0〜20Lu 程度のルジオン值か確 認された場合となる. 本研究では隣接孔で 0 20Lu が確 認された場合の対象ステージのルジオン值を予測するこ とに重点をおき, $20 \mathrm{Lu}$ 以上のデー夕も $20 \mathrm{Lu}$ としてスケー リングし入力することにした. つまり, ルジオン值の最 小值として $0(\mathrm{Lu})$ ，最大值として $20(\mathrm{Lu})$ を設定した.

\section{(2) 隣接孔の単位注入セメント重量}

隣接孔の単位注入セメント重量は, 定量的な数値デー タであり, 単位孔長 $(1 \mathrm{~m})$ あたりに注入されたセメントの 重量である. 人力デー夕は, 左右隣接ステージ上中下を 採用し，二ューロン数は 6 とした. 単位注入セメント重 量は0〜約 $10000(\mathrm{~kg} / \mathrm{m})$ 範囲でデー夕か採取されたが, $2000(\mathrm{~kg} / \mathrm{m})$ を超えるデー夕は全体数の約 $1 \%$ 程度であった. 学習範囲をむやみに広くするとシステム構築に問題があ る場合が多く ${ }^{14)}$, 数值の上限を設け, $2000(\mathrm{~kg} / \mathrm{m})$ 以上の 
表-8 岩級区分の変換数

\begin{tabular}{|c|c|}
\hline 岩級区分 & 変換数 \\
\hline $\mathrm{CH}$ 級 & 1.00 \\
\hline $\mathrm{CM}$ 級 & 0.66 \\
\hline $\mathrm{CL}$ 級 & 0.33 \\
\hline $\mathrm{D}$ 級 & 0.00 \\
\hline
\end{tabular}

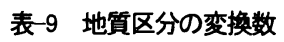

\begin{tabular}{|c|cc|}
\hline 地質区分 & \multicolumn{2}{|c|}{ 変換数 } \\
\hline 安山岩系 & 0 & 0 \\
\hline 貫入岩系 & 0 & 1 \\
\hline 角喽岩系 & 1 & 0 \\
\hline
\end{tabular}

表-10 目薬効果影響ステージ数の変換数

\begin{tabular}{|c|c|}
\hline 目薬ステー擞 & 変換数 \\
\hline 0 & 0 \\
\hline 1 & 1 \\
\hline 2 & 2 \\
\hline 3 & 2 \\
\hline 4 & 2 \\
\hline 5 & 2 \\
\hline 6 & 2 \\
\hline
\end{tabular}

データも $2000(\mathrm{~kg} / \mathrm{m})$ として人力した. つまり, 隣接孔の 単位注入セメント重量は, 最小値として $0(\mathrm{~kg} / \mathrm{m})$, 最大值 として $2000(\mathrm{~kg} / \mathrm{m})$ を設定した.

\section{(3) 土被り}

土被りは定量的な数値データであり, ニューロン数は 1 とした. 土被りの最小值は約 $90 \mathrm{~m}$ であり, 最大值は約 $210 \mathrm{~m}$ である.

\section{(4) 岩級区分}

岩級区分は順序を有する定性的な区分デー夕である. 対象地点の岩級はCH 級,CM 級 CL 級およびD級の 4 種類て あった，岩級区分の範囲境界は，ステージ毎に区分した 領域の境界とは一致していないため, 最も面積を専有し ている岩級区分により代表させた，岩級区分は強度の大 きい順にCH 級，CM 級，CL 級 D 級となり，表-8に示すよう な変換数を入力した. 人力ニューロン数は 1 とした.

\section{(5) 地質区分}

地質区分も岩級区分と同様にステージ中で最も面積を 占有しているものを採用した. 地質区分は，順序を有さ ない定性的な区分デー夕である. 対象地点のデー夕は安 山岩系, 貫入岩系, 角砅岩系の 3 種類に大別でき, 1 つの デー夕に対して表-9 に示すような変換数を採用した. 入 カニューロンは 2 とした.

\section{(6) 目薬効果}

隣接孔のルジオン值がその上ステージの影響を受けて 過小評価されるていると対象ステージのルジオン值の予 測に問題が生じる. 本研究では，3.（2）d）で検討したよ うに左右隣接ステージ上中下の中でその上ステージの単 位注入セメント重量が $500(\mathrm{~kg} / \mathrm{m})$ 以上となっているステ
ージを目薬効果を受けたと仮定して，その合計数を「目 薬ステーシ擞」とした. 表-10に採用した変換数を示す. 目薬ステージ数が 2 以上のデー夕は全体数の約 18 程度で あったため目薬ステー溇が 2 以上のものは，まとめて 変換数 2 を採用した. 目薬ステージ数は定量的な数值デ 一タであり, 入力ニューロン数は 1 とした.

\section{(7) 対象ステージのルジオン值}

出力デー夕は対象ステージのルジオン值である. 対象 ステージのルジオン值は定量的な数值データであり, 出 力ニューロン数は 1 とした. 対象ステージのルジオン值 屯隣接ステージのルジオン值と同様な理由により，スケ ーリングをした. ルジオン值の最小值として $0(\mathrm{Lu})$, 最大 値として 20(Lu)を設定した.

\section{5. ニューラルネットワークシステムの構築}

\section{(1) 利用したデータ}

4. でも示したが，ニューラルネットワークシステム の構築に際しては，K夕゙ム建設地点の左岸リム部カーテ ングラウチング施工部の 1 部領域のうち, 出力值が 3 次 孔のデー夕を利用した. 図-15に学習用領域, 検証用領域, 予測用領域を示す. 前者の 2 つは, システムの構築に使 用されるもので，後者は本システムの実用への妥当性を 評価するために設けたデータである. 学習用デー夕は 2 〜 ブロックのデー夕を採用し, 検証用デー夕は 2 5 ブ ロックの中から無作為に数量で約 10\%を抽出した. 予測用 領域は 1 ブロックとした.

\section{（2）システムの決定}

本研究では, 教師付きの学習法である階層型ニューラ ルネットワークを採用した．中間層は一般的によく用い られる 1 層モデルを採用している. 中間層のニューロン 数はそれを決定する一般的な考え方は無いが，多くする と複雑な現象の説明もできるが過学習状態になりやすく， 少なくすると複雑な現象を説明しづらくなるが過学習状 態になりにくいという傾向がある ${ }^{15)}$. 本研究では最適の 中間層の二ューロン数を決定するために, 人力ニューロ ン数の $0.3 \sim 2.0$ 倍の中間層の二ューロン数を設定し計算 した．その中で推定認識䛊差が最も小さい中間層の二ュ 一ロン数として入力ニューロン数の約 0.5 倍の数 $(9$ 二ュ 一ロン)を採用した. また, シグモイド関数の温度は, 0.2 ２.0 が適切之されており，本研究では 1 を採用した. 本 研究で採用したニューラルネットワークシステムを図一 16 に示す.

図-17に学習回数と平均誤差の推移を示す. 図より, 約 1000 回の学習で平均推定䛊差が最小となっており, その ときの平均認識鿁差は約 $1.5(\mathrm{Lu})$ であった，本研究では 


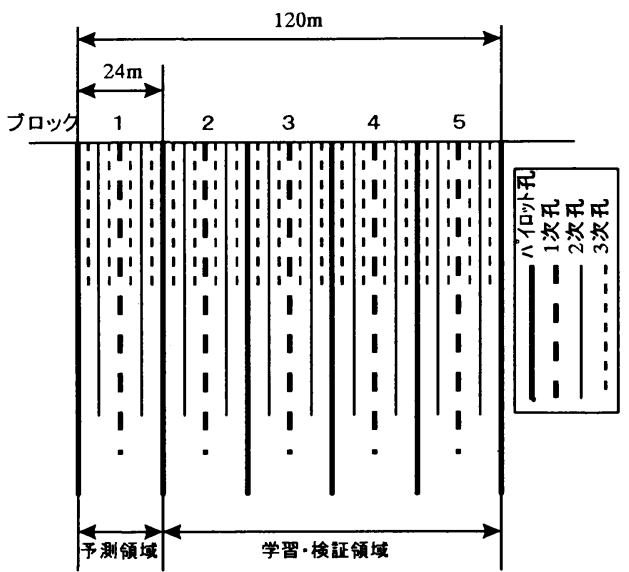

図-15 学習・検証・予湘領域の模式図

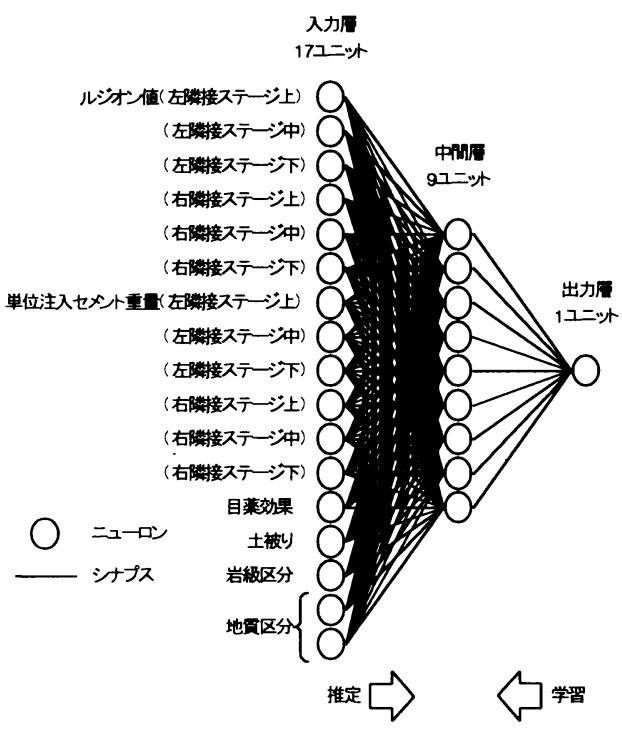

図-16 ニューラルネットワークシステムの模式図

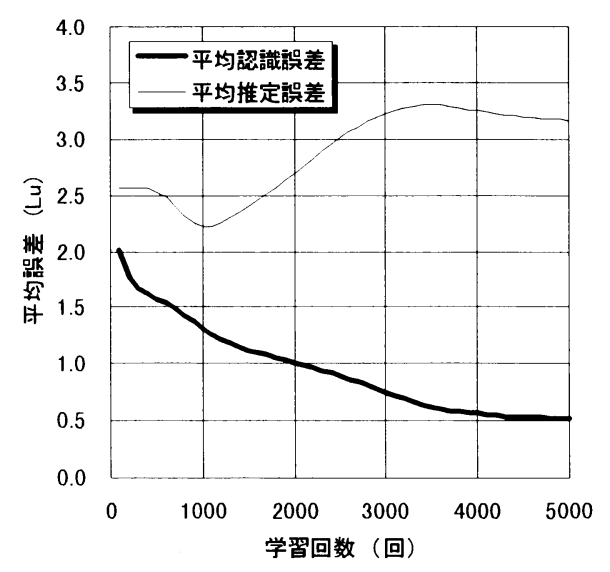

図-17 学習回数によるシステムの平均誤差の推移

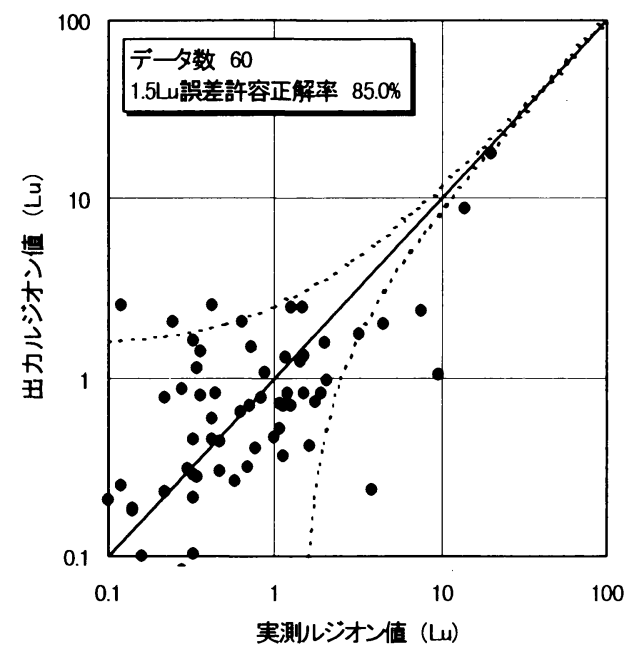

図-18 学習デー夕の諗識結果

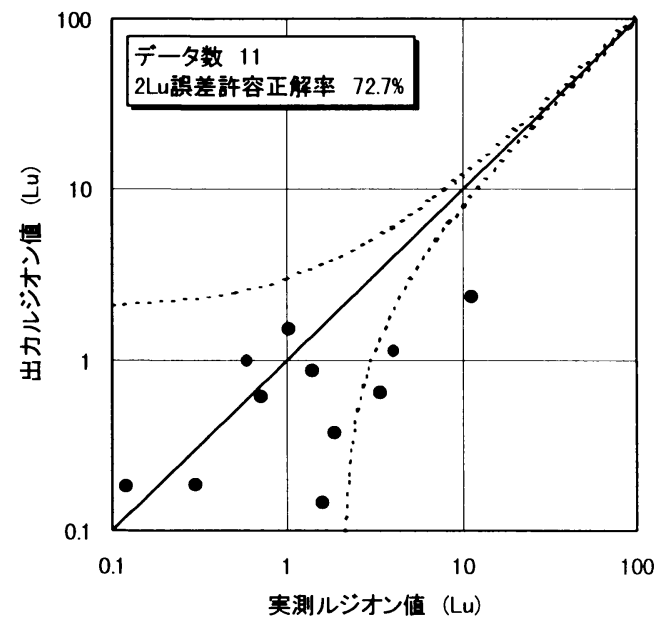

図-19 検証データの認識結果

図-17 より平均推定䛊差の最小となる学習回数 1000 回を 採用することにした. 図-18,19に学習デー夕および検証. デー夕の認識結果を示す. 図中のルジオン值はそれぞれ 対数軸で表現している. さらに極めて小さいルジオン値 は誤差の範囲に含まれると考えられるため, 実測ルジオ ン值および出力ルジオン值は $0.1(\mathrm{Lu})$ 以上のデー夕のみ に限定して示している. 学習回数 1000 回での平均認識愦 差は約 $1.5(\mathrm{Lu})$, 平均推定䛊差は約 $2.0(\mathrm{Lu})$ であることか ら, 実測ルジオン值と出力ルジオン值の差分が学習デー 夕は土1.5(Lu)以内, 検証デー夕は $\pm 2.0(\mathrm{Lu})$ 以内之なる ものを正解，その他を不正解デー夕とする. 図-18，19で は，正解・不正解領域を分ける線を破線で示している. 
表-11 感度解析の各項目の基準値

\begin{tabular}{|c|c|c|c|c|}
\hline & \multicolumn{4}{|c|}{ 基準值 } \\
\hline & CASE-1S & CASE-1D & \multicolumn{1}{|c|}{ CASE-2S } & CASE-2D \\
\hline $\begin{array}{c}\text { 隣接孔レジ } \\
\text { オン值 }\end{array}$ & \multicolumn{2}{|c|}{$2 \mathrm{Lu}$} & \multicolumn{3}{|c|}{$10 \mathrm{Lu}$} \\
\hline $\begin{array}{c}\text { 隣接孔セメ } \\
\text { ント量 }\end{array}$ & \multicolumn{2}{|c|}{$100 \mathrm{~kg} / \mathrm{m}$} & \multicolumn{2}{|c|}{$300 \mathrm{~kg} / \mathrm{m}$} \\
\hline 土被り & $100 \mathrm{~m}$ & $200 \mathrm{~m}$ & $100 \mathrm{~m}$ & $200 \mathrm{~m}$ \\
\hline 地質区分 & \multicolumn{5}{|c|}{ 貫入岩系 } \\
\hline 岩級区分 & \multicolumn{5}{|c|}{ CH 級 } \\
\hline
\end{tabular}

学習データでは約 85\%, 検証データでは約 73\%の正解率で あった. 学習デー夕および検証デー夕の誤答したデー夕 は極めて外れているものは少なく，システムとしては良 好なものであるといえる.

\section{(3) 感度解析}

本二ューラルネットワークシステムの各因子が経験的 な感度と合致するかどうかを検討するために感度解析を 実施した. 感度解析とは, 各入力因子が出力値にどの程 度影響しているかを検証するものである．本研究の感度 解析では，感度を知りたい入力因子以外の入力因子は基 準値を入力し, 感度を知りたい入力因子を最小値から最 大値まで変化させたときの出力値の変化を感度として算 出した ${ }^{16)}$. 基準值は平均値もしくは最頻值を採用する場 合が多く, 本研究では表 5 に示すような 4 ケースの感度 解析を実施した. CASE-1S は隣接孔のルジオン值が小さく 土被りが小さい場合, CASE-1D は隣接孔のルジオン值が 小さく土被りが大きい場合, CASE-2S は隣接孔のルジオ ン值が大きく土被りが小さい場合, CASE-2D は隣接孔の ルジオン值が大きく土被りが大きい場合の感度解析であ る. 隣接孔の単位注入セメント重量はルジオン值と相関 があるため, ルジオン值が小さいときは $100(\mathrm{~kg} / \mathrm{m})$, ルジ オン值が大きいときは $300(\mathrm{~kg} / \mathrm{m})$ を採用した. 地質区分, 岩級区分は最も多い種類として貫入岩系とCH級を採用し た. 目薬ステージ数は対象ステージのルジオン值に直接 影響する因子ではないので感度解析の対象外とした．図 -20 (a) 〜 (e) に感度解析結果を示す. 以下に各入力項目の 感度の傾向について示す.

\section{a) 隣接孔のルジオン値}

図-20(a) より, 全てのケースにおいて隣接孔のルジオ ン值は大きくなるほどニューラルネットワークの出力值 は大きくなる. 土被りが小さく, 隣接孔の単位注入セメ ント重量が小さいものほどその傾向は顕著である. 土被 りが小さいことは表層部に近く, 岩艋が高透水性である ことを示しており，隣接孔の単位注入セメント重量が小 さいことはグラウチングによる改良度合いが少ないこと を意味している. どちらの場合にも対象ステージのルジ オン值は大きくなることから感度解析結果が妥当である

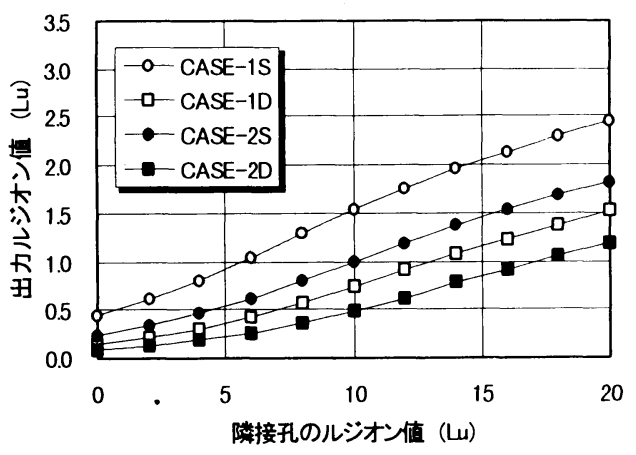

図-20（a）感度解析結果（隣接孔のルジオン值）

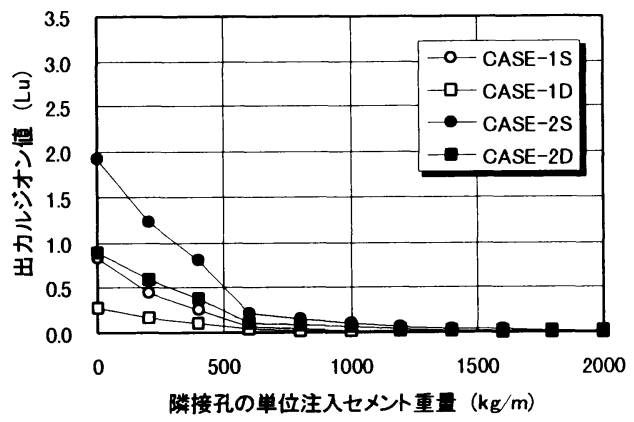

図-20(b) 感度解析結果（隣接孔の単位注入セメント重量）

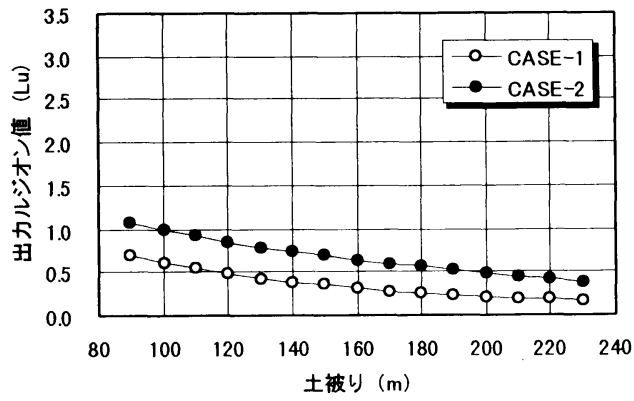

図-20(c) 感度解析結果（土被り）

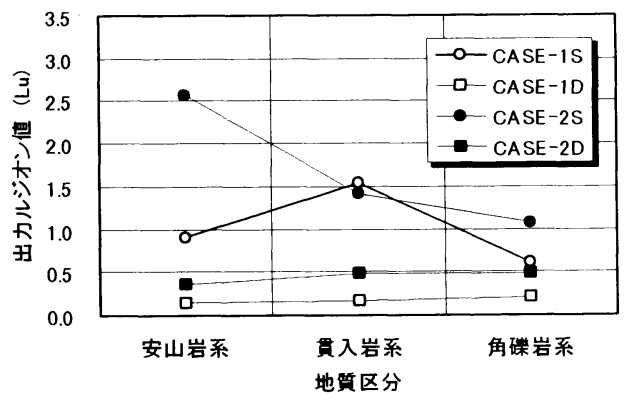

図-20(d) 感度解析結果（地質区分） 


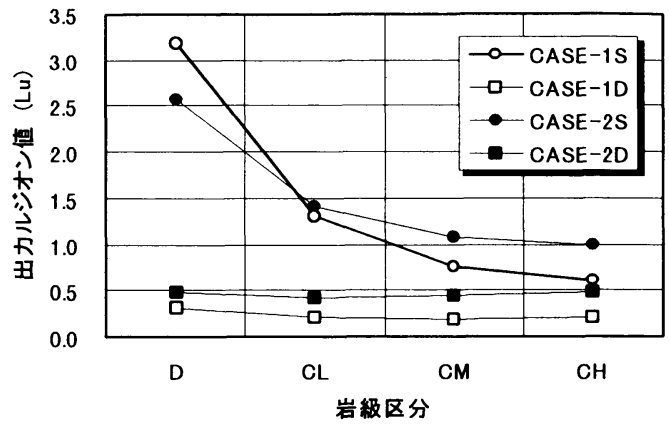

図-20（e） 感度解析結果（岩級区分）

ことがわかる.

\section{b) 隣接孔の単位注入セメント重量}

一般に単位注入セメント重量が大きくなると対象ステ 一ジのルジオン值は大きくなる. 図-20(b)より, 全ての ケースにおいて隣接孔の単位注入セメント重量は大きく なるほどニューラルネットワークの出力値は小さくなっ ており, 前述の傾向とは逆になっている. 単位注入セメ ント重量はルジオン值と追従するものであり, その値の 中には岩盤内の透水性を示す部分とグラウチングの改良 度合いを示す部分が含まれている. 図-20(b)の各值はル ジオン值を一定にした場合の感度解析であり, グラウチ ングの改良度合いの部分のみを示している. つまり, 感 度としては従来からの知見と一致している. グラウチン グの改良効果は隣接孔の単位注入セメント重量が $0(\mathrm{~kg} / \mathrm{m})$ のときの出力ルジオン值と隣接孔の単位注入セ メント重量がある值のときの出力ルジオン值の差分で与 えられる. 隣接孔の単位注入セメント重量か釉 $600(\mathrm{~kg} / \mathrm{m})$ 以上ではグラウチングによる改良効果がほとんど一定に 収束している. これは, 高透水性の領域では極めて大量 のセメントが注入されるため, 隣接孔の単位注入セメン 卜重量が対象ステージのルジオン值に対して無感度にな るためである.

c) 土被り

図-20(c)より，全てのケースにおいて土被りは大きく なるほどニューラルネットワークの出力値は小さくなる. これは, 土被りの増加に伴って岩盤内の透水性が小さく なっていることを表している.

d) 地質区分

図-20(d)より，地質区分は土被りが大きい場合にはほ とんど無感度になっている.これは土被りが大きくなる 之地質に関係なく，透水性が小さくなることを表してい る. 土被りが小さい場合には，貫入岩系および角磻岩系 ではニューラルネットワークの出力値に大差は無いが, 安山岩系では大きく異なっている.これは, 安山岩系の 地質の分布位置に偏りがあるためと考えられるが，明確 に判断はできない.

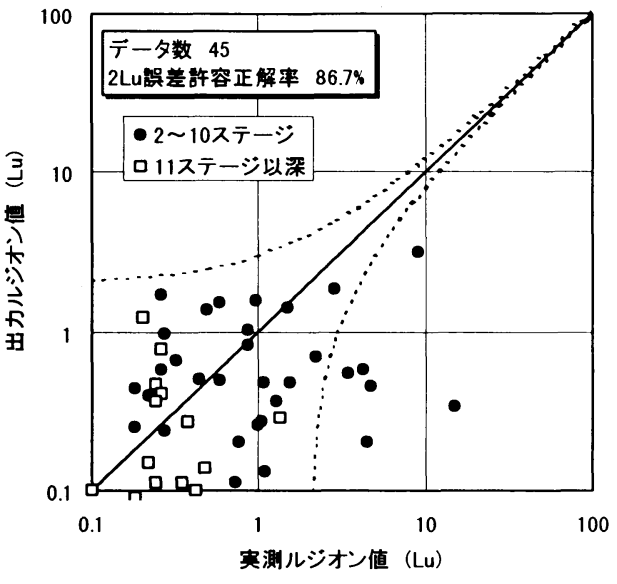

図-21 予測解析結果

\section{e) 岩級区分}

図-20(e)より，岩級区分は土被りが大きい場合にはほ とんど無感度になっている.これは土被りが大きくなる と岩級区分に関係なく，透水性が小さくなることを表し ている. 土被りが小さい場合にはルジオン值に関係なくD 級が最もニューラルネットワークの出力值が大きい.こ れは既往の知見亡一致する.

以上より，各感度は現場技術者のもつ豊富な経験と合 致しており，本解析で構築したニューラルネットワーク システムの有効性か明らかとなった。

\section{6. システムの実適用}

構築されたシステムを用い，未施工部分のルジオン值 を予測することが可能かどうかについての検証を行った 予測用領域 (1 ブロック) のルジオン值を左右隣接ステー ジ上中下から予測し，実測值とどの程度合致するかを検 討した. 図-21に予測解析結果を示す. 図は予測ルジオン 值と実測ルジオン值の差分が 2 Lu 以内にあるものを正 解，その他を不正解としている. 図より約 87\%の正解率で ルジオン值の予測か可能であることがわかる. さらに, 図のデー夕は深度 0 10 (ステージ) と 11 ステージ以深 とで区分して示している. 不正解デー夕の全てが 0 10 (ステージ) にあり, 本システムにより 3 次孔の 11 ステ ージ以深の予測が十分可能であることがわかる. 実施工 では施工深度を決定する際に深部のデー夕が重要となる ことから, 3 次孔以降の施工深度を決定する際に本システ ムが有効であり, グラウチング工事のコスト縮减に寄与 できる可能性があることがわかる. 


\section{7. まとめ}

本研究は, 対象ステージのルジオン值に影響する内子 について検討し，様々な影響因子と対象ステージのルジ オン値との関係について明らかにした. その結果をもと にニューラルネットワークを利用して, 隣接孔のデータ から対象孔のルジオン值を予測するシステムを提案し, 実用上有効であるとの知見を得た．本研究で得られた知 見を以下に列挙する.

(1) 対象ステージのルジオン值に影響する因子について 統計解析を行い整理した. その結果, 隣接孔のルジオン 值，隣接孔の単位注入セメント重量，土被り，岩級区分， 地質区分, 目薬ステーシ擞と対象ステージのルジオン值 との関係を明らかにした。

(2) 構築されたニューラルネットワークシステムの正解 率は学習データで約 $85 \%$ 程度, 検証データで約 $73 \%$ 程度と 高く, システムとして十分適用可能であった. さらに, 感度解析より，ルジオン值に影響する因子として従来よ り経験的に把握されていたものを定量的に示すことがで きた。

(3) 構築されたニューラルネットワークシステムを用い て未施工部分の予測解析を実施した. その結果, 約 87\% 程度の正解率で実測値之整合するものであり, 特に 3 次 孔の深部での予測では良好な出力値か得られた. これら の結果からグラウチング工事のコスト縮減に寄与できる 可能性があるとの知見を得た.

以上より, 本解析で使用したニューラルネットワーク がルジオン值の推定に有効であることが実証できた、ル ジオン值の定量的な予測が可能となったことは極めて意 義があり, グラウチング工事管理の手段の一つとして用 いられると考えられる. 今後は，より精度の良いシステ ムの開発を目指すつもりである.

\section{参考文献}

1）(社）土木学会 : ダム基磼岩盤グラウチングの施工指針，啓 文堂, 1972 .

2)建設省河川局開発課監修: ルジオンテスト技術指針・同解説 (財) 国土開発技術研究センター, 1984.

3)例えば，島裕雅、斎藤秀樹 : ジオトモグラフィーの岩盤調査 への適用性について一数值実験による検討一, 第7回岩の力 学国内シンポジウム講演論文集, pp.175-180, 1987.
4)例えば，島裕雅、斎藤秀樹 : 弾性波トモグラフィーと比抵抗 トモグラフィーを用いた岩盤調査, 物理探査学会第 80 回学術 講演会論文集，pp.51-56，1989.

5)播田一雄、田淵弘、浅津直樹, 古川浩平, 中川浩二: ダムの止 水グラウチングに関する一考察, 第21 回岩盤力学に関するシ ンポジウム講演論文集,pp.101-105,1989.

6)例えば，合原一幸：ニューロコンピュータ, 東京電気大学出 版局, 1988.

7)奥田宏明，西野健三，飯酒益久夫，古田島信義 : グラウチン グ改良効果に関する現場実験とその考察, 応用地質,第 33 巻,2 号, 1992.

8)宇田進一, 重田満, 中尾誠司 : 孔壁展開画像による調査精度 の向上について, ダム工学,No.17, 1995,3.

9)西山孝、楠田啓，陳友晴，寺田直道，蛭子清二 萩森賢治： 蛍光法とボアホールテレビジョンシステムを用いた孔壁の割 れ目の抽出, 応用地質, 第 36 巻,6号, 1996.

10）「土と基䃈」講座委員会 : 地下水位の測定, 土之基䃈, Vol.17,No.11,pp. 40.1969.

11)中屋眞司, 西垣誠: 地質学的情報を用いた亀裂性岩盤の透水 性評価，地下水技術，第 35 巻，第 9 号， 1993.

12)吉中龍之准，桜井春輔，菊地宏吉: 岩盤分類之その適用 pp. 39-61, 土木工学社, 1989.7.

13）寺戸康隆 : ダム基礎グラウチング ( I ) (IX), ダム日本 No.443-452,1981.9-1982.6.

14)市川鉱 : 階層型ニューラルネットワークー非線形問題の応用 一, 共立出版 (株)，1993.6.

15)知川元基: 計算力学と CAE シリーズ 12 「ニューラルネット ワークー計算力学・応用力学への応用」, pp.146-148, 培風館, 1992.5.

16)安田登, 松島学, 安田武 飯島健 : ニューラルネットワーク を用いた岩盤グラウト注入効果の評価システムの構筑，土木 学会, 構造工学論文集、Vol.42A、1996.4.

(1998. 5. 22 受付) 


\section{PREDICTION SYSTEM FOR LUGEON VALUES IN ROCK MASS USING NEURAL NETWORK SYSTEM}

\section{Norio KAINUMA, Noboru YASUDA, Manabu MATSUSHIMA, Takayuki NAKAGAWA, Kenichi KANTOU and Naoto YOSHINO}

In generally, the quality control using Lugeon values is carried out in order to construct the curtain line for water tightness on dam construction. The grouting construction has been completed by the decision of engineers who have rich experience.

The system to predict the Lugeon value of target hole by the Lugeon value of next hole is proposed using neural network system in this paper. Then, prediction of Lugeon value of target hole can be carried out successfully by using proposed system instead of engineer who has rich experience on grouting. 